American J. of Engineering and Applied Sciences 3 (2): 300-306, 2010

ISSN 1941-7020

(C) 2010 Science Publications

\title{
Taguchi Experiment Design for Investigation of Freshened Properties of Self-Compacting Concrete
}

\author{
${ }^{1,2}$ Yoyok Setyo Hadiwidodo and ${ }^{1}$ Sabarudin Bin Mohd \\ ${ }^{1}$ Faculty of Civil Engineering and Earth Resources, University Malaysia Pahang, Malaysia \\ ${ }^{2}$ Department of Ocean Engineering, Faculty of Marine Technology, \\ Institute Technology Sepuluh Nopember (ITS), Surabaya, 60111 Indonesia
}

\begin{abstract}
Problem statement: The intent of this study was to apply of Taguchi Design Of Experiments (DOE) techniques in Self Compacting Concrete (SCC) freshened properties studies. Owing to a wide range of material content of Self Compacting Concrete (SCC), generally, a large number of experiments were usually required as to decide a suitable mixture for finding the needed requirements of SCC. Approach: For that purpose, Taguchi's approach with an $\mathrm{L}_{18}\left(2^{1} \times 3^{7}\right)$ orthogonal array and three-level factor to reduce the numbers of experiment was adopted. Six control factors, namely, contents of coarse aggregate, sand, cement, silica fume, water and superplasticizer were used. The mixtures were extensively tested in freshened state and to meet technical requirement of SCC. Four responses (slump flow, flow time, V-funnel, L-box and segregation resistance) were evaluated. Results: The result of this study showed that Taguchi method is a promising approach for optimizing mix proportions of SCC to meet several freshened concrete properties. Conclusion: This study has shown that it possible to design self compacting concrete with fulfilling the criteria. As it can be seen in the results of freshened concrete properties of produced concrete samples, they fulfilled the expected properties of SCC.
\end{abstract}

Key words: Freshened properties, self-compacting concrete, Taguchi method

\section{INTRODUCTION}

In an experimental study, in order to determine the effects of various factors, which are affecting the results of experiment, different methods and approaches are used. The fundamentals of these methods are the full factorial design and fractional factorial design (Montgomery, 2004). In the traditional approach, which is also known as full factorial design, the experiments are performed for each condition, which consists of all factors. In the experiments where the number of factor and their levels are few, the full factorial experimental design may be applied to the design.

Assume an engineering experiment study requires n control factors and three control levels per control factor to understand the influence and interaction of its input data on the output results. By using a traditional experimental process, usually at least all the possible $3^{\text {n }}$ tests need to be carefully conducted and finished before an optimal performance can be concluded. The number of tests can get very large really fast.

Owing to a wide range of variability of material content of Self Compacting Concrete (SCC), generally, a large number of experiments are usually required as to decide a suitable mixture for attaining the targeted requirements of SCC. So the fractional factorial experiments using orthogonal array was investigated by Taguchi, which can substantially decrease the number of experiments and feasible to study the effect of factors and its interactions.

In this article, the Taguchi approach is proposed to select the optimal mixture proportioning of SCC based on the freshened stage requirement on the slump flow, flow time, blocking ratio and V-funnel time. Although several other researchers also studied properties of concrete (Srinivasan et al., 2003; Turkmena et al., 2008; Tanyildizi and Coskun, 2008; Tanyildizi, 2008) by using Taguchi method, they generally change one or two constituents of concrete and they investigate the effect of those parameters on concrete.

\section{MATERIALS AND METHODS}

Material: The SCC mixes investigated in this study were prepared with crushed gravel with a nominal maximum size of $14 \mathrm{~mm}$. Natural sand used was as fine aggregate with less than $50 \%$ passing through the 
Am. J. Engg. \& Applied Sci., 3 (2): 300-306, 2010

$0.50 \mathrm{~mm}$ sieve. The particle size gradation obtained through the sieve analysis and physical properties of the fine and coarse aggregates are presented in Table 1. An ordinary Portland Cement (CEM II/A-M) in conformity with BS EN 197-1 (2000) standard was used to produce the various SCC mixtures. In addition, a Silica Fume (SF) was used as mineral admixtures. Table 2 summarizes physical properties and chemical composition of the cement and mineral admixtures used. A polycarboxylic-ether type Superplasticizer (SP) with a specific gravity of 1.07 was employed to achieve the desired workability in all concrete mixtures.

Design of experiment: Taguchi constructed a special set of Orthogonal Arrays (OAs) to lay out his experiment. By combining the orthogonal Latin squares in a unique manner, Taguchi prepared a new set of standard of OAs to be used for a number of experiment situations (Roy, 1990). Using orthogonal arrays significantly reduces the number of experimental configurations to be studied. In this study, $\mathrm{L}_{18}$ Orthogonal Array (OA) is used. The standard $\mathrm{L}_{18} \mathrm{OA}$ is shown in Table 3. By using the different values of control factors in Table 4 and the standard L18 OA shown in Table 3, 18 sets of mixture proportion of SCC are calculated and shown in Table 5.
Table 1: Properties of aggregate

\begin{tabular}{lcc}
\hline & Coarse aggregate & Natural sand \\
\hline Specific gravity of coarse aggregate & 2.65 & 2.64 \\
Bulk density of coarse aggregate & 1515.00 & 1497.00 \\
Water absorption (\%) & - & - \\
Sieve, cumulative \% passing & - & - \\
$20.0 \mathrm{~mm}$ & 100.00 & - \\
$14.0 \mathrm{~mm}$ & 94.00 & - \\
$10.0 \mathrm{~mm}$ & 64.00 & - \\
$5.00 \mathrm{~mm}$ & 52.00 & 100.00 \\
$2.36 \mathrm{~mm}$ & 8.00 & 98.60 \\
$1.18 \mathrm{~mm}$ & 0.00 & 98.60 \\
$0.60 \mathrm{~mm}$ & - & 32.30 \\
$0.30 \mathrm{~mm}$ & - & 5.60 \\
$0.15 \mathrm{~mm}$ & - & 0.50 \\
Pan & 0.00 & 0.00 \\
\hline
\end{tabular}

Table 2: Properties of Portland Cement (OPC) and silica fume

\begin{tabular}{lll}
\hline Chemical composition & OPC $(\%)$ & Silica fume $(\%)$ \\
\hline Calcium Oxide $(\mathrm{CaO})$ & 65.0 & $<1$ \\
Silicon dioxide $\left(\mathrm{SiO}_{2}\right)$ & 20.1 & $>90$ \\
Aluminum oxide $\left(\mathrm{Al}_{2} \mathrm{O}_{3}\right)$ & 4.90 & $<1$ \\
Ferric Oxide $\left(\mathrm{Fe}_{2} \mathrm{O}_{3}\right)$ & 2.50 & $<1$ \\
Magnesium Oxide $(\mathrm{MgO})$ & 3.10 & $<1$ \\
Sulphur Oxide $\left(\mathrm{SO}_{3}\right)$ & 2.30 & $<1$ \\
Potassium oxide $\left(\mathrm{K}_{2} \mathrm{O}\right)$ & 0.40 & $<1$ \\
Sodium oxide $\left(\mathrm{Na}_{2} \mathrm{O}\right)$ & 0.20 & $<1$ \\
Loss on ignition $(\%)$ & 2.40 & $<3.0$ \\
Physical properties & & \\
Specific gravity & 3.10 & $2.2-2.3$ \\
Bulk density $\left(\mathrm{kg} \mathrm{m}^{-3}\right)$ & & $150-700$ \\
Particle size $(\mu \mathrm{m})$ & $45-150$ & $0.15-0.50$
\end{tabular}

Table 3: Standard $\mathrm{L}_{18}$ Orthogonal Array (OA)

\begin{tabular}{|c|c|c|c|c|c|c|c|c|}
\hline \multirow{2}{*}{$\begin{array}{l}\text { Experiment } \\
\text { Number }\end{array}$} & \multicolumn{8}{|c|}{ Control factors } \\
\hline & Variable 1 & Variable 2 & Variable 3 & Variable 4 & Variable 5 & Variable 6 & Variable 7 & Variable 8 \\
\hline 1 & 1 & 1 & 1 & 1 & 1 & 1 & 1 & 1 \\
\hline 2 & 1 & 1 & 2 & 2 & 2 & 2 & 2 & 2 \\
\hline 3 & 1 & 1 & 3 & 3 & 3 & 3 & 3 & 3 \\
\hline 4 & 1 & 2 & 1 & 1 & 2 & 2 & 3 & 3 \\
\hline 5 & 1 & 2 & 2 & 2 & 3 & 3 & 1 & 1 \\
\hline 6 & 1 & 2 & 3 & 3 & 1 & 1 & 2 & 2 \\
\hline 7 & 1 & 3 & 1 & 2 & 1 & 3 & 2 & 3 \\
\hline 8 & 1 & 3 & 2 & 3 & 2 & 1 & 3 & 1 \\
\hline 9 & 1 & 3 & 3 & 1 & 3 & 2 & 1 & 2 \\
\hline 10 & 2 & 1 & 1 & 3 & 3 & 2 & 2 & 1 \\
\hline 11 & 2 & 1 & 2 & 1 & 1 & 3 & 3 & 2 \\
\hline 12 & 2 & 1 & 3 & 2 & 2 & 1 & 1 & 3 \\
\hline 13 & 2 & 2 & 1 & 2 & 3 & 1 & 3 & 2 \\
\hline 14 & 2 & 2 & 2 & 3 & 1 & 2 & 1 & 3 \\
\hline 15 & 2 & 2 & 3 & 1 & 2 & 3 & 2 & 1 \\
\hline 16 & 2 & 3 & 1 & 3 & 2 & 3 & 1 & 2 \\
\hline 17 & 2 & 3 & 2 & 1 & 3 & 1 & 2 & 3 \\
\hline 18 & 2 & 3 & 3 & 2 & 1 & 2 & 3 & 1 \\
\hline
\end{tabular}

Table 4: Parameters and their variation levels

\begin{tabular}{lllllll}
\hline Levels & $\begin{array}{l}\text { A: Coarse aggregate } \\
\left(\mathrm{kg} \mathrm{m}^{-3}\right)\end{array}$ & $\begin{array}{l}\text { B: Fine aggregate } \\
\left(\mathrm{kg} \mathrm{m}^{-3}\right)\end{array}$ & $\begin{array}{l}\text { C: Cement } \\
\left(\mathrm{kg} \mathrm{m}^{-3}\right)\end{array}$ & $\begin{array}{l}\text { D: Silica } \\
\left(\mathrm{kg} \mathrm{m}^{-3}\right)\end{array}$ & $\begin{array}{l}\text { E: Water } \\
\left(\mathrm{kg} \mathrm{m}^{-3}\right)\end{array}$ & $\begin{array}{l}\text { F: SP } \\
\left(\mathrm{kg} \mathrm{m}^{-3}\right)\end{array}$ \\
\hline 1 & 759.00 & 833.98 & 538.29 & 43.44 & 230.14 & 4.11 \\
2 & 767.25 & 826.26 & 546.20 & 45.35 & 233.09 & 4.48 \\
3 & 775.50 & 818.53 & 554.11 & 47.26 & 236.04 & 4.84 \\
\hline
\end{tabular}


Am. J. Engg. \& Applied Sci., 3 (2): 300-306, 2010

Table 5: Details of mix concrete proportions

\begin{tabular}{lllllll}
\hline $\begin{array}{l}\text { Experiment } \\
\text { Number }\end{array}$ & $\begin{array}{l}\text { Factor 1 } \\
\text { A: Coarse } \\
\left(\mathrm{kg} \mathrm{m}^{-3}\right)\end{array}$ & $\begin{array}{l}\text { Factor } 2 \\
\text { B: Fine } \\
\left(\mathrm{kg} \mathrm{m}^{-3}\right)\end{array}$ & $\begin{array}{l}\text { Factor 3 } \\
\text { C: Cement } \\
\left(\mathrm{kg} \mathrm{m}^{-3}\right)\end{array}$ & $\begin{array}{l}\text { Factor 4 } \\
\text { D: Silica Fume } \\
\left(\mathrm{kg} \mathrm{m}^{-3}\right)\end{array}$ & $\begin{array}{l}\text { Factor 5 } \\
\text { E: Water } \\
\left(\mathrm{kg} \mathrm{m}^{-3}\right)\end{array}$ & $\begin{array}{l}\text { Factor 6 } \\
\text { F: } \mathrm{p} \\
\left(\mathrm{kg} \mathrm{m}^{-3}\right)\end{array}$ \\
\hline 1 & 759.00 & 818.53 & 538.29 & 43.44 & 230.14 & 4.11 \\
2 & 759.00 & 826.26 & 546.20 & 45.35 & 233.09 & 4.48 \\
3 & 759.00 & 833.98 & 554.11 & 47.26 & 236.04 & 4.84 \\
4 & 767.25 & 818.53 & 538.29 & 45.35 & 233.09 & 4.84 \\
5 & 767.25 & 826.26 & 546.20 & 47.26 & 236.04 & 4.11 \\
6 & 767.25 & 833.98 & 554.11 & 43.44 & 230.14 & 4.48 \\
7 & 775.50 & 818.53 & 546.20 & 43.44 & 236.04 & 4.48 \\
8 & 775.50 & 826.26 & 554.11 & 45.35 & 230.14 & 4.84 \\
9 & 775.50 & 833.98 & 538.29 & 47.26 & 233.09 & 4.11 \\
10 & 759.00 & 818.53 & 554.11 & 47.26 & 233.09 & 4.48 \\
11 & 759.00 & 826.26 & 538.29 & 43.44 & 236.04 & 4.84 \\
12 & 759.00 & 833.98 & 546.20 & 45.35 & 230.14 & 4.11 \\
13 & 767.25 & 818.53 & 546.20 & 47.26 & 230.14 & 4.84 \\
14 & 767.25 & 826.26 & 554.11 & 43.44 & 233.09 & 4.11 \\
15 & 767.25 & 833.98 & 538.29 & 45.35 & 236.04 & 4.48 \\
16 & 775.50 & 818.53 & 554.11 & 45.35 & 236.04 & 4.11 \\
17 & 775.50 & 826.26 & 538.29 & 47.26 & 230.14 & 4.48 \\
18 & 775.50 & 833.98 & 546.20 & 43.44 & 233.09 & 4.84 \\
\hline
\end{tabular}

\section{RESULTS}

The results of freshened properties test are discussed in the following paragraphs. Freshened properties of SCC were observed through slump-flow, flow time, V-funnel, L-box and Segregation Resistance.

Experimental findings: Freshened properties concrete test results are presented in Table 6. The slump-flow values of all concrete mixtures were in the range of 650$800 \mathrm{~mm}$, which refers to the mean spread diameter of concrete following the removal of slump cone as specified by EFNARC (2002). However, it is not enough to verify the self compactability of these mixtures. Additionally, the speed of slump-flowing (i.e., $\mathrm{T}_{50}$ time), passing ability and visual stability of mixtures should also be tested. The slump-flow Time $\left(\mathrm{T}_{50}\right)$ of all mixtures were in the range of targeted times (approximately 2-5 s). The slump-flow Time $\left(\mathrm{T}_{50}\right)$ was measured when the concrete was slumping until it reached $500 \mathrm{~mm}$ of flow. Very low $\mathrm{T}_{50}$ times may cause segregation and very high $\mathrm{T}_{50}$ times may cause blocking. Visual stability index is a well known and the simplest method of detection of any evidence of stability loss in fresh SCCs. The visual stability indices of all mixtures were varied between 0 and 1 which indicates a good segregation resistance. Additionally, satisfactory blocking resistances were obtained from L-box tests. L-box passing ability ratios of all mixtures were higher than 0.80 .

Statistical performance characteristic analysis of the results: In the Taguchi experiment design, a loss function is used to calculate the deviation between the experimental value and the desired value. Taguchi used
Gauss's quadratic function to evaluate quality. His quality loss function quantitatively evaluates quality loss due to a product's functional variation. Furthermore, the quality loss function can be directly used to evaluate quality improvement from a designed experiment. From the quality point of view, there are three possible categories of quality characteristics so that the Taguchi's quality loss functions for the three categories are given below:

- $\quad$ Smaller is better: $\mathrm{L}(\mathrm{y})=\mathrm{ky}^{2}$

- Larger is better: $\mathrm{L}(\mathrm{y})=\frac{\mathrm{k}}{\mathrm{y}^{2}}$

- Nominal is better: $\mathrm{L}(\mathrm{y})=\mathrm{k}(\mathrm{y}-\mathrm{m})^{2}$

The loss function is further transformed into utility function. The utility function developed by Taguchi is called the Signal-to-Noise $(\mathrm{S} / \mathrm{N})$ ratio to determine the statistical performance characteristic deviating from the desired value. The $\mathrm{S} / \mathrm{N}$ ratio for the ith performed characteristic in the jth experiment can be expressed as:

$$
\mathrm{S} / \mathrm{N}=-10 * \log _{10}\left(\mathrm{~L}_{\mathrm{ij}}\right)
$$

where, $\left(\mathrm{L}_{\mathrm{ij}}\right)$ is the lost function.

The aim of any experiment is always to determine the highest possible of $\mathrm{S} / \mathrm{N}$ ratio of the results. A high value of $\mathrm{S} / \mathrm{N}$ implies that the signal is much higher than the random effects of the noise factors. Noise factors are viewed as the causes of variability in performance, including why products fail. A noise factor is anything that causes a measurable product or process characteristic to deviate from its target value. Target values may be. 
Am. J. Engg. \& Applied Sci., 3 (2): 300-306, 2010

Table 6: Results of freshened properties test

\begin{tabular}{|c|c|c|c|c|c|}
\hline $\begin{array}{l}\text { Experiment } \\
\text { Number }\end{array}$ & $\begin{array}{l}\text { Response } 1 \\
\text { slump flow (mm) }\end{array}$ & $\begin{array}{l}\text { Response } 2 \\
\mathrm{~T}_{50}(\mathrm{sec})\end{array}$ & $\begin{array}{l}\text { Response } 3 \\
\text { V-funnel (sec) }\end{array}$ & $\begin{array}{l}\text { Response } 4 \\
\text { L-box (blocking ratio) }\end{array}$ & $\begin{array}{l}\text { Response } 5 \\
\text { segregation resistance (\%) }\end{array}$ \\
\hline 1 & 740.0 & 3.09 & 9.42 & 0.98 & 10.09 \\
\hline 2 & 665.0 & 4.95 & 11.78 & 0.99 & 9.49 \\
\hline 3 & 695.0 & 4.38 & 12.91 & 0.87 & 6.97 \\
\hline 4 & 740.0 & 2.90 & 12.09 & 0.84 & 5.26 \\
\hline 5 & 720.0 & 2.76 & 13.75 & 0.86 & 5.48 \\
\hline 6 & 735.0 & 3.09 & 9.09 & 0.91 & 6.48 \\
\hline 7 & 720.0 & 3.84 & 12.06 & 0.90 & 7.40 \\
\hline 8 & 700.0 & 5.48 & 12.62 & 0.89 & 8.70 \\
\hline 9 & 710.0 & 5.07 & 12.75 & 0.90 & 1.20 \\
\hline 10 & 705.0 & 5.10 & 12.65 & 0.91 & 11.77 \\
\hline 11 & 737.5 & 3.54 & 11.73 & 0.88 & 9.00 \\
\hline 12 & 690.0 & 5.28 & 8.69 & 0.92 & 13.52 \\
\hline 13 & 695.0 & 4.23 & 11.41 & 0.83 & 7.73 \\
\hline 14 & 680.0 & 5.20 & 11.65 & 0.80 & 14.65 \\
\hline 15 & 690.0 & 5.73 & 13.84 & 0.98 & 14.16 \\
\hline 16 & 720.0 & 3.81 & 10.52 & 0.87 & 13.94 \\
\hline 17 & 710.0 & 3.31 & 9.54 & 0.87 & 13.47 \\
\hline 18 & 717.5 & 4.32 & 9.37 & 0.89 & 13.55 \\
\hline
\end{tabular}

Table 7: Optimal mix design proportions for freshened properties SCC

\begin{tabular}{lllllll}
\hline Optimal mix proportions & Coarse $\left(\mathrm{kg} \mathrm{m}^{-3}\right)$ & Sand $\left(\mathrm{kg} \mathrm{m}^{-3}\right)$ & Cement $\left(\mathrm{kg} \mathrm{m}^{-3}\right)$ & $\mathrm{SF}\left(\mathrm{kg} \mathrm{m}^{-3}\right)$ & $\mathrm{Water}\left(\mathrm{kg} \mathrm{m}^{-3}\right)$ & $\mathrm{Sp}\left(\mathrm{kg} \mathrm{m}^{-3}\right)$ \\
\hline Slump flow & 775.50 & 818.53 & 546.20 & 45.35 & 233.09 & 4.48 \\
Flow time & 775.50 & 818.53 & 554.11 & 45.35 & 233.09 & 4.48 \\
Block ratio & 759.00 & 818.53 & 546.20 & 45.35 & 230.14 & 4.48 \\
V-funnel time & 767.25 & 826.26 & 554.11 & 47.26 & 236.04 & 4.84 \\
Segregation resistance & 759.00 & 826.26 & 554.11 & 45.35 & 230.14 & 4.48 \\
\hline
\end{tabular}

Smaller is better: Choose when goal is to minimize the response, e.g., minimum flow time $\mathrm{T}_{50}$ of SCC. The $\mathrm{S} / \mathrm{N}$ ratio can be calculated as given in Eq. 1 for smaller the better:

$\mathrm{S} / \mathrm{N}=-10 * \log _{10}\left(\frac{1}{\mathrm{n}} \sum_{\mathrm{k}=1}^{\mathrm{n}} \mathrm{Y}_{\mathrm{i}}^{2}\right)$

Larger is better: Choose when goal is to maximize the response, e.g., maximum expected slump flow, compressive, tensile and flexural strength of SCC. The $\mathrm{S} / \mathrm{N}$ ratio is calculated as given in Eq. 2 for larger the better:

$\mathrm{S} / \mathrm{N}=-10 * \log _{10}\left(\frac{1}{\mathrm{n}} \sum_{\mathrm{i}=1}^{\mathrm{n}} \frac{1}{\mathrm{Y}_{\mathrm{i}}^{2}}\right)$

Nominal is better: Choose when goal is to target the response and it is required to base the $\mathrm{S} / \mathrm{N}$ ratio on standard deviations only. The $\mathrm{S} / \mathrm{N}$ ratio is calculated as given in Eq. 3 for smaller the better:

$\mathrm{S} / \mathrm{N}=-10 * \log _{10}\left(\frac{1}{\mathrm{n}} \sum_{\mathrm{i}=1}^{\mathrm{n}}\left(\mathrm{Y}_{\mathrm{i}}-\mathrm{Y}_{0}\right)^{2}\right)$

where in Eq. 1-3, Y shows the measured value of each responses.
The objective is to select the best combination of control parameters so that the product or process is most robust with respect to noise factors. The control factors and the levels gives in Table 3 were used for calculating the $\mathrm{S} / \mathrm{N}$ ratio. The $\mathrm{SN}$ ratios of slump flow, flow time, block ratio, V-funnel and segregation resistance were calculated for each level of the experimental parameters given in Table 4. Figure 1-5 show the SN response of each level of the experimental parameters. The best possible testing conditions of the SCC freshened properties can be determined from the main effect plot graphs from Fig. 1-5 for slump flow, flow time, blocking ratio, V-funnel and segregation resistance, respectively. According to the Fig. 1-5, the best mix proportions of the target properties are tabulated in Table 7.

\section{DISCUSSION}

Slump test values of all mixes are in the range 650-800 mm. As it mentioned in EFNARC (2002), concretes can be accepted SCC if their slump flow values are in the range $650-800 \mathrm{~mm}$. It can be said that all produced concretes are SCC. According to Fig. 1, the optimal mix proportions for slump flow SCC is obtained by A3 B3C2D3E3F2 combinations. 
Am. J. Engg. \& Applied Sci., 3 (2): 300-306, 2010

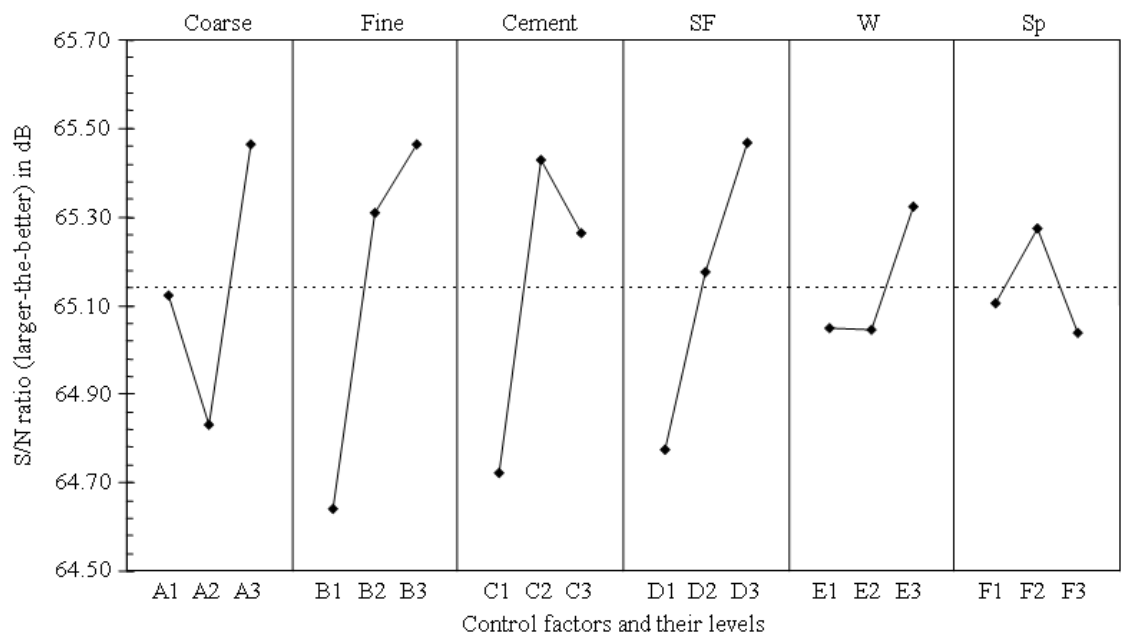

Fig. 1: Factor effect plot for slump flow

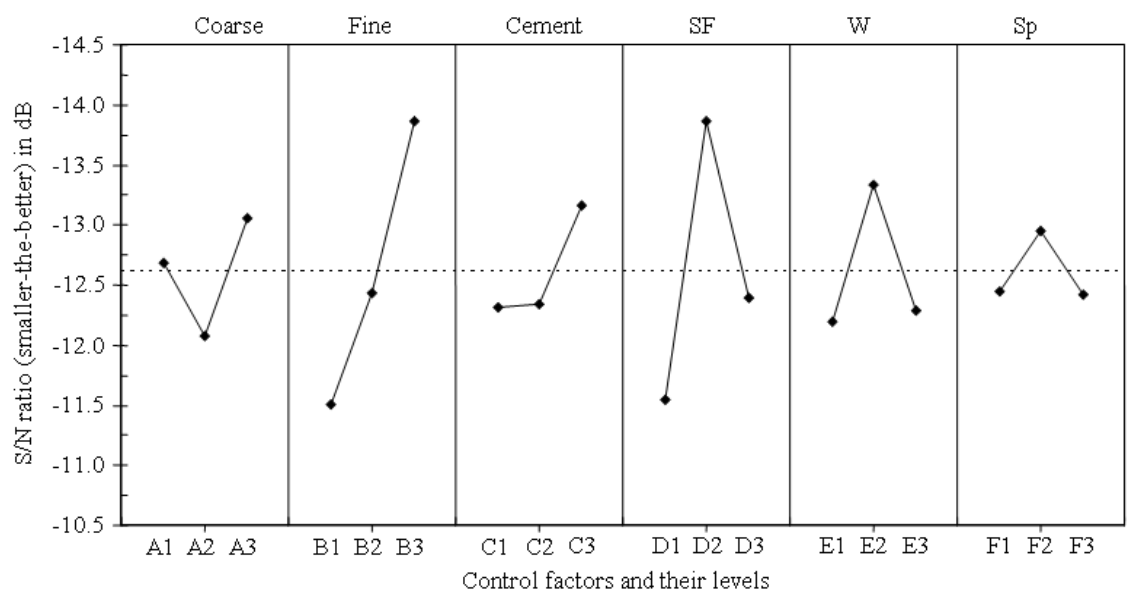

Fig. 2: Factor effect plot for flow time $\left(\mathrm{T}_{50}\right)$

The slump flow is increased in the concrete mix within increasing of fine aggregate and silica fume. The slump flow test is used to assess the horizontal free flow of SCC in the absence of obstructions. On lifting the slump cone, filled with concrete, the concrete flows. The average diameter of the concrete circle is a measure for the filling ability of the concrete Aggarwal et al. (2008). The time $\mathrm{T}_{50} \mathrm{~cm}$ is a secondary indication of flow. It measures the time taken in seconds from the instant the cone is lifted to the instant when horizontal flow reaches diameter of $500 \mathrm{~mm}$. The effect plot of concrete ingredient on flow time $\mathrm{T}_{50}$ is shown in Fig. 2. According to Fig. 4, the optimal mix proportion for flow time SCC is obtained by A3B3C3D2E2F2 combinations.

Blocking ratio assesses filling and passing ability of SCC. If the concrete flows as freely as water, at rest it will be horizontal, so $\mathrm{H} 2 / \mathrm{H} 1=1$. Therefore the nearer this test value, the 'blocking ratio', is to unity, the better the flow of the concrete. As it can be seen from Fig. 3, the optimal mix proportion for blocking ratio SCC is obtained by combination of A1B3C2D2E1F2. For the L-box test, the increase of the dosages of water and Sp led to an increase in the L-box blocking ratio. This is an agreement with results found in previous study (Sonebi et al., 2007).

This V-funnel test measures the ease of flow of the concrete; shorter flow times indicate greater flowability. For SCC a flow time of $10 \mathrm{sec}$ is considered appropriate. Optimal conditions for Vfunnel time are obtained by mixture combination A2B2C3D3E3F3 as shown in Fig. 4. When silica fume, water and superplasticizer content are increased in concrete increased the $\mathrm{V}$-flow time. 
Am. J. Engg. \& Applied Sci., 3 (2): 300-306, 2010

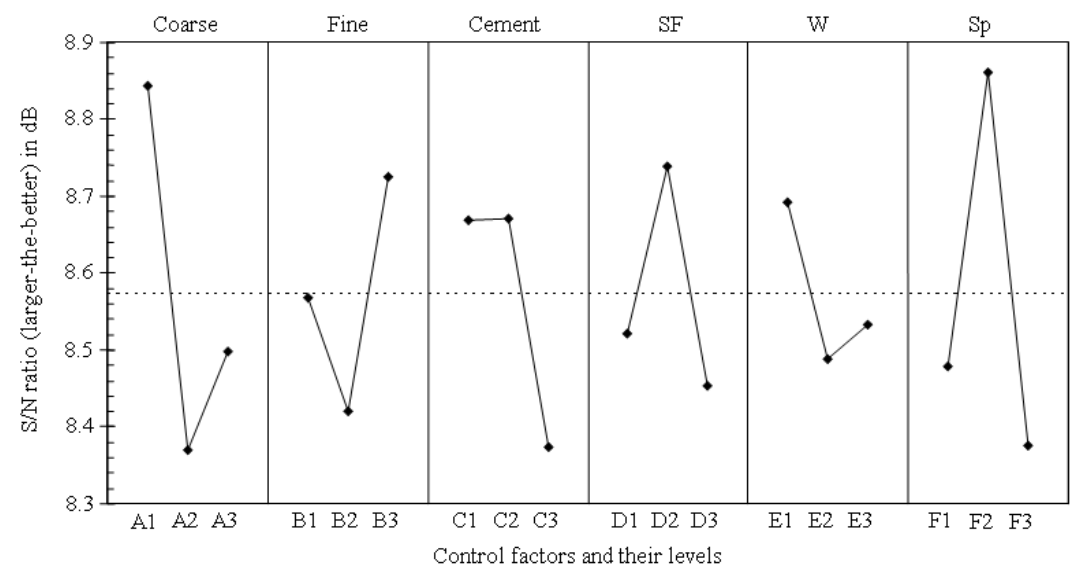

Fig. 3: Factor effect plot for blocking ratio

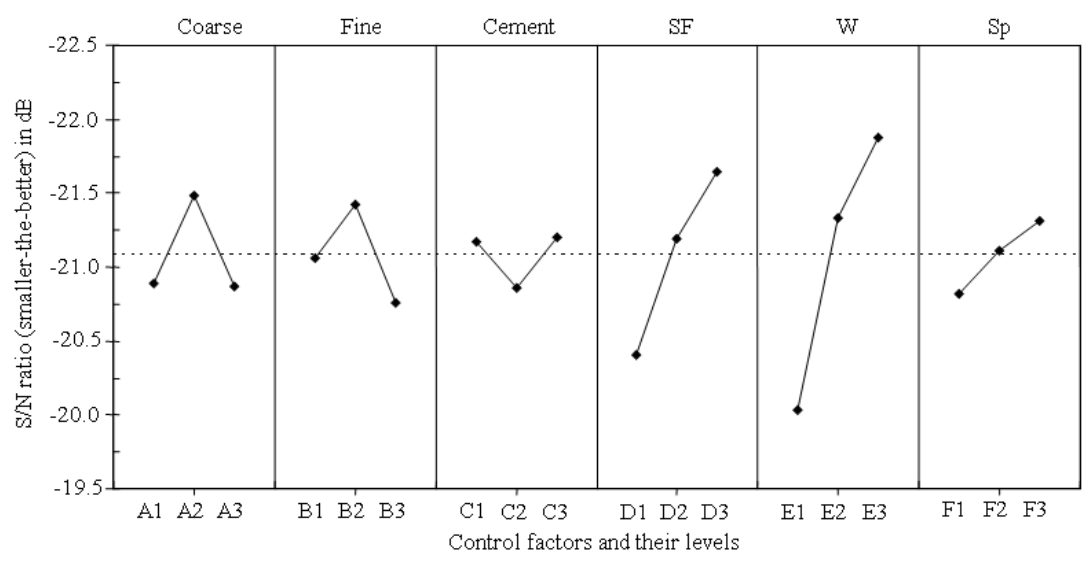

Fig, 4: Factor effect plot for V-funnel time

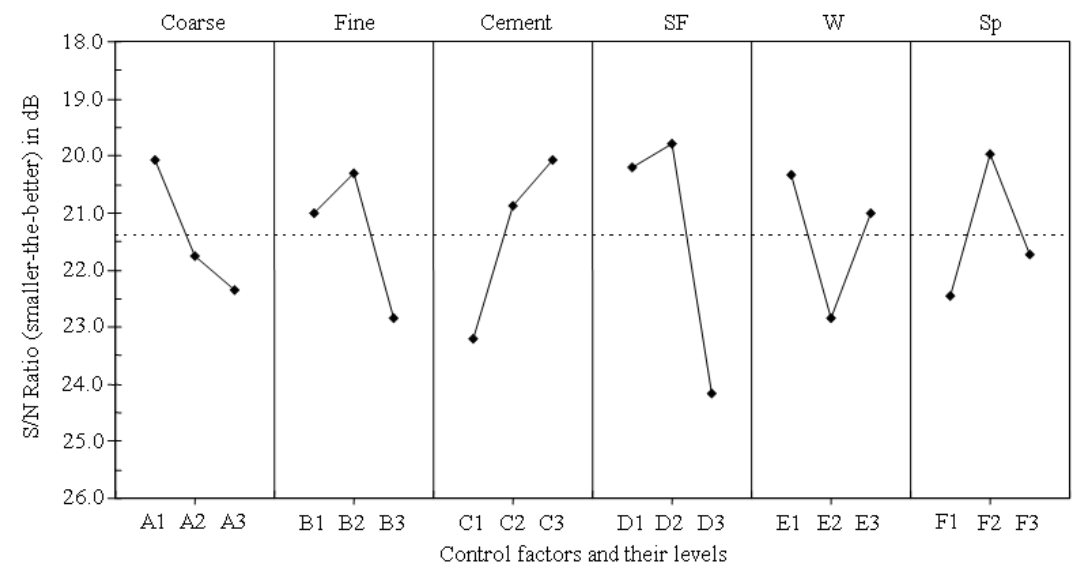

Fig. 5: Factor effect plot for segregation resistance

The segregation resistance is increasing within increased of cement content, nevertheless decreased of coarse aggregate. The optimal conditions for segregation resistance are obtained by mixture 
A1B2C3D2E1F2 as shown Fig. 5. The systematic experimental approach showed that partial replacement of coarse and fine aggregate could produce selfcompacting concrete with low segregation potential as assessed by the V-Funnel test (Ravindrarajah et al., 2003).

\section{CONCLUSION}

SCC is consisting of many components; it is critical to use a systematic approach for identifying optimal mixes and investigate the most effective factors under a set of constraints. Due to this reason Taguchi method with $\mathrm{L}_{18}\left(3^{6}\right)$ orthogonal array is used in this study to investigate ranking of the effective parameters and best possible mix proportions of fresh properties of SCC. At the end of this research, it is seen that Taguchi method is a promising approach for optimizing mix proportions of SCC to meet several freshened concrete properties. Taguchi method can simplify the test procedure required to optimize mix proportion of SCC by reducing the number of trial batches. This study has shown that it possible to design self compacting concrete with fulfilling the criteria. As it can be seen in the results of freshened concrete properties of produced concrete samples, they fulfilled the expected properties of SCC.

\section{REFERENCES}

Aggarwal, P., R. Siddique, Y. Aggarwal and S.M. Gupta, 2008. Self-compacting concrete-procedure for mix design. Leonardo Elect. J. Practices Technol., 12: $15-24$.

BS EN 197-1, 2000. Cement. Composition, Specifications and Conformity Criteria for Common Cements. British-Adopted European Standard, ISBN: 9780580580451, pp: 52.
EFNARC, 2002. Specification and guidelines for selfcompacting concrete. http://www.efnarc.org/pdf/SandGforSCC.PDF

Montgomery, D.C., 2004. Design and Analysis of Experiments. 6th Edn., John Wiley and Sons, USA.

Ravindrarajah, R.S., D. Siladyi and B. Adamopoulos, 2003. Development of high-strength selfcompacting concrete with reduced segregation potential. Proceedings of the 3rd International RILEM Symposium, (RILEMS'03), RILEM Publications, Reykjavik, Iceland, pp: 1048.

Roy, R., 1990. A Primer on the Taguchi Method. Van Nostrand Reinhold, ISBN: 0-442-23729-4, pp: 247.

Sonebi, M., S. Grünewald and J. Walraven, 2007. Filling ability and passing ability of selfconsolidating concrete. ACI Mater. J., 104: 162-170.

Srinivasan, C.B., N.L. Narasimhan and S.V. Ilango, 2003. Development of rapid-set high-strength cement using statistical experimental design. Cem. Concr. Res. 33: 1287-1292. DOI: 10.1016/S00088846(03)00041-3

Tanyildizi, H. and A. Coskun, 2008. Performance of lightweight concrete with silica fume after high temperature. Constr. Build. Mater., 22: 2124-2129. DOI: 10.1016/j.conbuildmat.2007.07.017

Tanyildizi, H., 2008. Effect of temperature, carbon fibers and silica fume on the mechanical properties of lightweight concretes. New Carbon Mater., 23: 339-344.

Turkmena, I., R. Gul and C. Celik, 2008. A Taguchi approach for investigation of some physical properties of concrete produced from mineral admixtures. Buil. Environ., 43: 1127-1137. DOI: 10.1016/j.buildenv.2007.02.005 